\title{
Socio-Economic Factors Affecting Choice Of Livelihood Activities Among Rural Dwellers In Southeast Nigeria
}

\author{
${ }^{1}$ Ifeanyi-obi, C.C and ${ }^{2}$ Matthews-Njoku, E.C \\ ${ }^{1}$ Department of agricultural Economics and Extension, University of Port Harcourt. \\ ${ }^{2}$ Department of agricultural Extension, Federal university of technology, Owerri.
}

\begin{abstract}
The broad objective of this study is to identify socio-economic determinants of choice of livelihood activity among rural dwellers in southeast Nigeria. Specifically, the study described the socio-economic characteristics of the rural dwellers in the study area, assessed livelihood activities in the study area and identified socio-economic determinants of choice of livelihood activity in the area. Multi-stage sampling technique was used to select one hundred and sixty rural dwellers for this study. Data was collected with the aid of structured interview schedule, focused group discussion and personal observation and analyzed using descriptive statistical tools namely; mean, frequency counts and percentages. Ordinary least square multiple regression analysis was used to identify socio-economic factors influencing choice of livelihood in the area. Result show that majority (57\%) were male, married (95\%) and above 40years $(87.5 \%)$, with the mean age of $54 y e a r s$. Respondents spent an average of 10 years in school, maintained mean household size of seven persons and earned mean monthly income of $\$ 21,000$. Farming and trading were found to be the major livelihood activity of the rural dwellers in the area with mean of 3.7 and 2.9 respectively. Age, years of education and monthly income was found to be the major socio-economic factors affecting livelihood activities in the area. Based on the findings of the study, it was recommended that government should improve farming with regards to mechanization of farming activities as to attract young graduates into the sector.
\end{abstract}

Keywords: Socio-economic, factors, rural dwellers, livelihood activities, southeast Nigeria.

\section{Introduction}

A rural area may be viewed from, or mean different thing to different people, depending on the country and level of development. A typical African rural area may not be the same as in a country like the United States of America or other developing countries. Traditionally in Nigeria, census figures had been used to differentiate rural area from urban areas. For instance, in 1953, the colonial government in Nigeria decided that an urban center is any compact settlement with a population of at least 5,000 persons while a settlement with less than 5,000 persons is a rural area. In the 1963 Nigeria census, an urban area was simply defined as one with a population of 20,000 or more inhabitants and any area with lesser population than 20,000 is regarded by implication as rural. But the fact that there is no consensus on the use of figures had made the use of census definition problematic. A rural area in Nigeria according to Ekong (2010) means a settlement with 20,000 persons or less whose occupations are mainly agrarian. He stressed that such settlement is usually associated with lack of, or inadequate basic infrastructure or amenities such as pipe-borne water, electricity, hospitals, good road network, industries, modern banking services, commercial/civic centres, recreational facilities, quality food e.t.c. It is an area of settlement in which half or more than half of the adult male working population is engaged in agricultural activities. This means that a greater population of the country is included irrespective of settlement pattern.

However, it does not just end in people working as farmers but anyone who lives in an incorporated area with less than 2,500 inhabitants is a rural resident. Also, with fast growth in development, it is difficult to identify rural area, since the indices of urbanization are appearing everywhere. Rural area used to be seen as places with low population densities but recent population explosions makes it difficult to pin point rural areas and many areas are merging together to give urban areas. Again most rural areas are heterogeneously occupied by people from various places or races, hence the homogeneity nature of rural areas can also said to be fading. According to Mgbada (2010), the rural areas are characterized by closeness to nature, farm and farm related occupation, low population density, small community size, homogenous community, strong social control, low standard/level of living, strong social cohesion, etc while the major problems of these areas include lack of or inadequate social, physical and institutional infrastructure. Rural areas regardless of the numerous challenges faced and negative connotation used to describe them play a lot of important roles in local government area, state and national development. Akpabio (2005) listed the importance of rural areas to be training ground for Nigeria's future leaders and technocrats, provide the bulk of food and raw material in the country, contribute to the nation's foreign exchange, constitutes the resources base of the nation by paying their taxes, consumers of 
equipment seeds, chemical and other farm inputs, consumer's goods and other durables thereby sustaining urban industries, potential sources of manpower, nurture and sustain the major institutions of religion and family etc Livelihood activities according to Ellis (1999) are the activities, assets and the access that jointly determine the living gained by the rural households. Carney, (1998) explain that it is sustainable when it has the capacity to meet the immediate needs of the people while its ability to meet future needs is not jeopardized. A livelihood can then be precisely said to comprise the capabilities, assets and activities required for a means of living and is sustainable when it can cope with and recover from stresses and shocks and maintain or enhance its capabilities and assets both now and in the future, while not undermining the natural resource base. In Nigeria, farming is known to be the major livelihood activity engaged by occupants of rural areas (Mgbado, 2010; Ekong 2005; Akpabio 2005). Although some rural dwellers are engaged in retail and petty trading, arts craft, weaving, pottery and other primary industries only a few tend to take these as sole occupations. Rather they tend to combine these with farming and greater proportions of them are full-time farmers.

\section{Objectives of the study}

The broad objective of this study is to identify socio-economic determinants of choice of livelihood activity in southeast Nigeria. Specifically, it:

- described the socio-economic characteristics of the rural dwellers in the study area;

- $\quad$ assessed livelihood activities in the study area and

- $\quad$ identified socio-economic determinants of choice of livelihood activity in the area.

\section{Methodology}

The study was conducted in southeast Nigeria. The southeast Nigeria is made up of five states namely; Anambra, Imo, Enugu, Abia and Ebonyi state. The predominant livelihood activity in the rural areas of this zone is farming though some have other income generating activities which they used to argument the income realized from farming. Most farmers in the zone cultivate with the major aim of feeding their family and selling off the remnant to generate income. Mixed farming is mostly practiced by farmers in the area.

Multi-stage sampling technique was used to select one hundred and sixty rural dwellers for the purpose of this study. Firstly, out of the five states that make up the zone, two were randomly selected. Then from each of the selected state, two agricultural zones were randomly selected giving a total of four agricultural zone for the study. Two blocks were randomly picked from each of the agricultural zone. Lastly two circles were randomly selected from each of the blocks and one hundred and sixty respondents were randomly selected from the chosen circles. Data was collected with the aid of structured interview schedule, focused group discussion and personal observation. Data collected were analysed using descriptive statistical tools namely; mean, frequency counts and percentages. The significance of livelihood activity done in the area was captured using a four point Likert-type scale of very significant, significant, less significant and not significant which was assigned weight of 4, 3, 2 and 1 respectively. A midpoint of 2.5 was obtained and based on this, decision rule was that any mean score greater than or equal to 2.5 implies that the livelihood activity contributes significantly to the wellbeing of the rural dwellers in the area while any mean score less than 2.5 implies that the livelihood activity does not contribute significantly to the wellbeing of the people. Ordinary least square multiple regression analysis was used to identify socio-economic factors influencing choice of livelihood in the area.

The OLS regression model that was used is implicitly stated as:

$\mathrm{Y}_{\mathrm{a}}=\mathrm{f}\left(\mathrm{X}_{1}, \mathrm{X}_{2}, \mathrm{X}_{3}, \mathrm{X}_{4}, \mathrm{X}_{5}, \mathrm{X}_{6 \mathrm{e}}\right)$

Where

$\mathrm{Y}_{\mathrm{a}}=$ Index of livelihood activity done by the rural dwellers in the area (based on statements measured on 4 point Likert-type rating scale of Very significant $=4$, Significant $=3$, Less significant $=2$, Not significant $=1$ )

$\mathrm{X}_{1}=$ Gender (dummy variable, male $=1$, female $=0$ )

$\mathrm{X}_{2}=$ Age (years)

$\mathrm{X}_{3}=$ Marital status (dummy variable, single $=0$, married $=1$ )

$\mathrm{X}_{4}=$ level of education (number of years spent in school)

$\mathrm{X}_{5}=$ Farming experience (years)

$\mathrm{X}_{6}=$ Household size ( no. of persons)

$\mathrm{e}=$ error term

It is expected a priori that the coefficients of $\mathrm{X}_{1} \mathrm{X}_{2}, \mathrm{X}_{3}, \mathrm{X}_{4}, \mathrm{X}_{5}, \mathrm{X}_{6}>0$

Four functional forms of the model namely linear, double log, exponential and semi-log was estimated. A lead equation was chosen based on the appropriateness of signs, magnitude of coefficient of multiple determination $\left(\mathrm{R}^{2)}\right.$, statistical significance of the variables and a priori theoretical expectations. The relationship between the dependent and each of the independent variables was examined using the four functional forms: linear, semi-log, exponential and double- $\log$.

Linear: $Y=B_{0}+B_{1} X_{1}+B_{2} X_{2}+B_{3} X_{3}+B_{4} X_{4}+B_{5} X_{5}+B_{6} X 6+e$ 
Semi-Log: $Y=B_{0}+B_{1} \log X_{1}+B_{2} \log X_{2}+B_{3} \log X_{3}+B_{4} \log X_{4}+B_{5} \log X_{5}+B_{6} \log X 6+e$

Exponential: $\log \mathrm{Y}=\mathrm{B}_{0}+\mathrm{B}_{1} \mathrm{X}_{1}+\mathrm{B}_{2} \mathrm{X}_{2}+\mathrm{B}_{3} \mathrm{X}_{3}+\mathrm{B}_{4} \mathrm{X}_{4}+\mathrm{B}_{5} \mathrm{X}_{5}+\mathrm{B}_{6} \mathrm{X}_{6}+\mathrm{e}$

Double Log: $\quad \log \mathrm{Y}=\mathrm{B}_{0}+\mathrm{B}_{1} \log \mathrm{X}_{1}+\mathrm{B}_{2} \log \mathrm{X}_{2}+\mathrm{B}_{3} \log \mathrm{X}_{3}+\mathrm{B}_{4} \log \mathrm{X}_{4}+\mathrm{B}_{5} \log \mathrm{X}_{5}+\mathrm{B}_{6} \log \mathrm{X} 6+\mathrm{e}$

$\mathrm{B}_{\mathrm{o}}=$ intercept

$\mathrm{B}_{1}, \mathrm{~B}_{2} \ldots \mathrm{B}_{11}=$ estimated coefficients

$\mathrm{e}=$ error term

\section{Result and Discussion}

\section{Socio-economic characteristics of rural dwellers}

The result in Table 1 show that majority (57\%) of the rural dwellers used for the study were male, married (95\%) and above 40years (87.5\%), with the mean age of 54years. This reveals that the respondents used for this study were mainly elderly people who have lived for relatively long number of years in their community. This could be said to be of advantage to the study as many of them are matured enough to give reasonable answers to the research questions. Only $2.5 \%$ had no formal education, $27.5 \%$ attended primary school while $70 \%$ had at least secondary education. The mean years spent in school is 10 years revealing that majority of the respondent finished primary education. Monthly income of the respondent was found to be mainly below $\$ 50,000(88.8 \%)$ with the mean monthly income of $\$ 21,000$. From the result, one could say that the rural dwellers of this zone are still struggling to have the basic necessity of life since they live on barely five dollars in day. Concerning the household size, majority $(66.3 \%)$ of the respondents had a household size of between $6-10$ persons with a mean household size of 7 persons. This results that the rural inhabitants of the southeast Nigeria maintain a relatively sizeable household which could serve as insurance against shortfalls in labour supply (Igben 1988). The major occupation of the rural dwellers in the zone was found to be farming (82.5\%). This agrees with Ekong (2010) which stated that rural dwellers in Nigeria have farming as their major livelihood activity.

Table 1: Socio-economic characteristics of rural dwellers in the study area.

\begin{tabular}{|c|c|c|c|}
\hline Variable & Frequency & Percentage & Mean \\
\hline \multicolumn{4}{|l|}{ Gender } \\
\hline Male & 91 & 57 & \\
\hline Female & 69 & 43 & \\
\hline Age & & & 54 \\
\hline $21-40$ & 20 & 12.5 & \\
\hline $41-60$ & 90 & 56.3 & \\
\hline $61-80$ & 46 & 27.6 & \\
\hline \multirow{2}{*}{\multicolumn{4}{|c|}{ Marital status }} \\
\hline & & & \\
\hline Single & 8 & 5 & \\
\hline Married & 152 & 95 & \\
\hline No. of years spent in school (Years) & & & 10 \\
\hline 0 (No formal education & 4 & 2.5 & \\
\hline $1-6$ & 44 & 27.5 & \\
\hline $7-13$ & 63 & 39.4 & \\
\hline $14-19$ & 45 & 28.1 & \\
\hline Above 19 & 4 & 2.5 & \\
\hline Monthly income ( & & & 21,000 \\
\hline$\leq 50,000$ & 142 & 88.8 & \\
\hline $51,000-1000,000$ & 16 & 10 & \\
\hline $101,000-150,000$ & 2 & 1.2 & \\
\hline Household size & & & 7 \\
\hline $1-5$ & 41 & 25.6 & \\
\hline $6-10$ & 106 & 66.3 & \\
\hline $11-15$ & 11 & 6.9 & \\
\hline $16-20$ & 2 & 1.3 & \\
\hline \multicolumn{4}{|l|}{ Major occupation } \\
\hline Farming & 132 & 82.5 & \\
\hline Non- farming & 28 & 17.5 & \\
\hline
\end{tabular}

Source: Field survey data, 2012

Sustainable livelihood activities of the rural dwellers in southeast Nigeria.

Table 2 shows the livelihood activities done by the rural dwellers in the study area. Out of twenty livelihoods used to capture their livelihood activities, only two were significant namely; farming (mean $=3.7)$ and trading (mean $=2.9$ ). This could mean that only this two livelihood activities can be said to be sustainable livelihoods in the area. This agrees with Adesope et al (2011), Ifeanyi-obi, et al (2011) and Nzeh and Eboh (2010) which states that farming and trading are the major livelihood activity done by rural dwellers in Nigeria. 
Socio-Economic Factors Affecting Choice Of Livelihood Activities Among Rural Dwellers In

Table 2:Distribution of respondents by sustainable livelihood activities

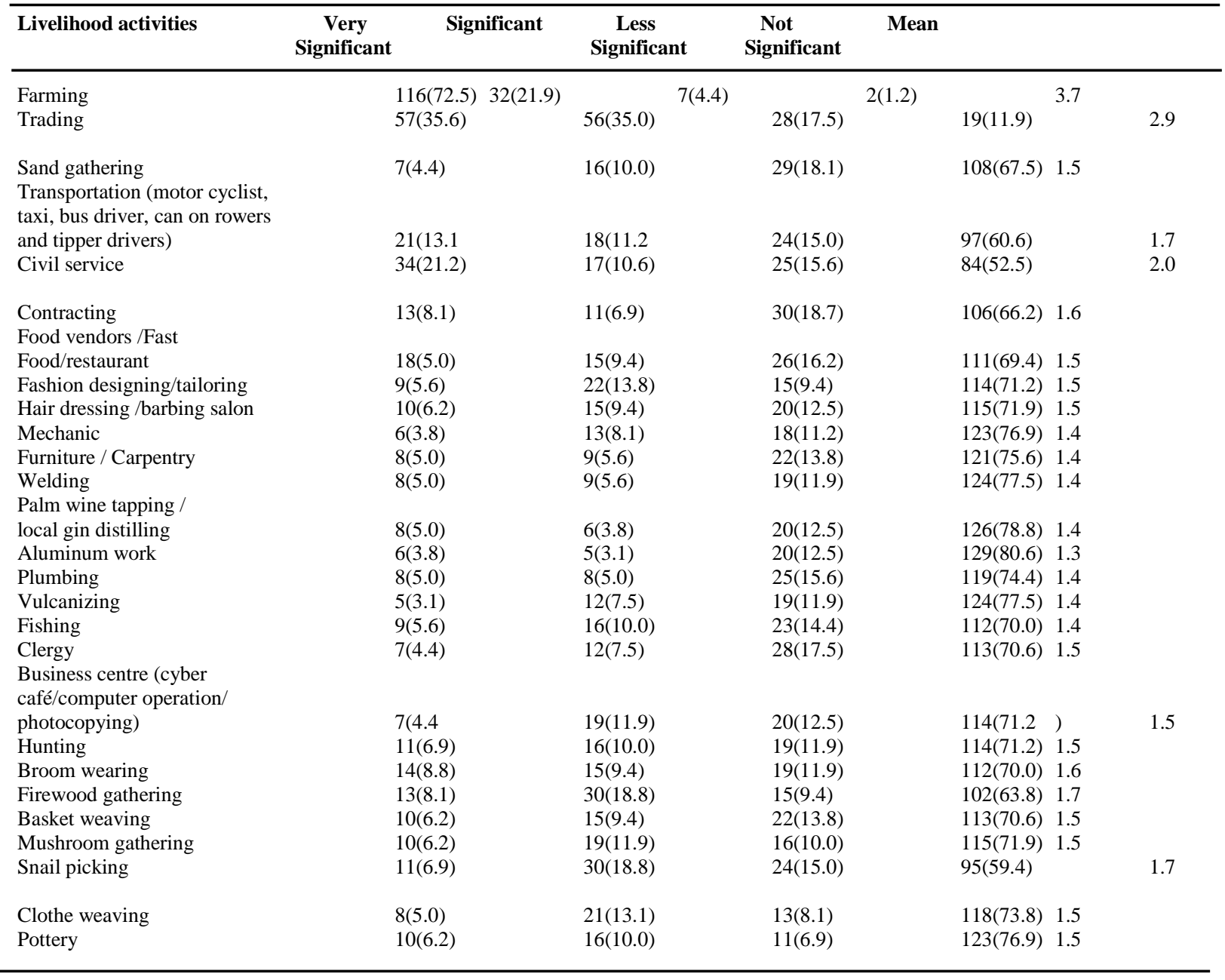

Source: Field survey data 2012

Mean score $\leq 2.50$ suggests the item is not significant

Mean score $\geq 2.5$ suggests the item is very significant

Socio-economic factors affecting choice of livelihood activity in the study area.

Results of the ordinary least square multiple regression analysis for the socio-economic factors affecting choice of livelihood activity in the study area are presented in Table 3. Linear functional form was chosen as the lead equation based on the value of $\mathrm{R}^{2}$, significant coefficients, F-value and conformity to apriori expectations of the regression coefficients. The coefficient of multiple determination $\left(\mathrm{R}^{2}\right)$ value of 0.441 shows that about $44.1 \%$ of the variation in livelihood activities could be explained by the socio-economic characteristics of the respondents while the remaining percentage was due to other factors not specified in the model. The F-value of 10.551 was significant at both $1 \%$ and $5 \%$ probability level implying that collectively all the variables have significant effect on the dependent variable. The Coefficient of gender, marital status and household size were not significant.

The coefficient of age is positively significant at both $1 \%$ and $5 \%$ probability level. This could imply that older rural inhabitants were more involved in farming activities. This could be attributed to farming being a traditional livelihood of the rural dwellers hence the dominance of farming in the rural area. Also, generally rural areas in Nigeria are known to be occupied by old people as youths mostly migrate to the urban areas in search of white collar jobs. In line with this, Chukwuezi (2001), Bryceson (2002) and Maegher (2001) noted the tendency for younger people to pursue multiple livelihood activities in the rural areas of Nigeria.

The coefficient of years of education correlated negatively with livelihoods activities with a t-value of 2.476 which was significant at both 0.01 and 0.05 probability level. This implies that the more educated rural dwellers in the study area abandon farming for other livelihood activities. This may not be surprising as the few rural dwellers who managed to acquire higher education are observed to abandon farming for other jobs with the reason that it involves hard labour with little income. This agrees with Adi (2007) which identified education as 
one of the determinants of livelihood strategy in Eastern Nigeria. Agricultural production in Nigeria generally is still highly non-mechanized. Farmers still employ the use of local tools in their farming activities, this has discouraged so many agricultural graduates who see it as degrading to carry hoe and matches to farm after spending years in higher institution while their counter parts in other areas are seen to work in well furnished offices. This has contributed so much to the problem of inadequate number of skilled personnel in the agricultural sector since many graduates of agriculture abandon the sector for other sector with mechanized production system as well as decent working equipment.

Lastly, the coefficient of monthly income correlated negatively with livelihood activity with a t-value of -8.060 which was significant at both 0.01 and 0.05 probability level. This could imply that rural dwellers who earn higher monthly income indulge in other livelihood activities (port- folio diversification) other than farming. This may be as a result of having more money which can enable them invest in other livelihood activity other than farming. Adi (2007) identified availability of fund as a significant variable in determining non-agricultural diversification.

Table 3: Ordinary least square regression analysis of socio-economic factors affecting choice of livelihood activity in the study area.

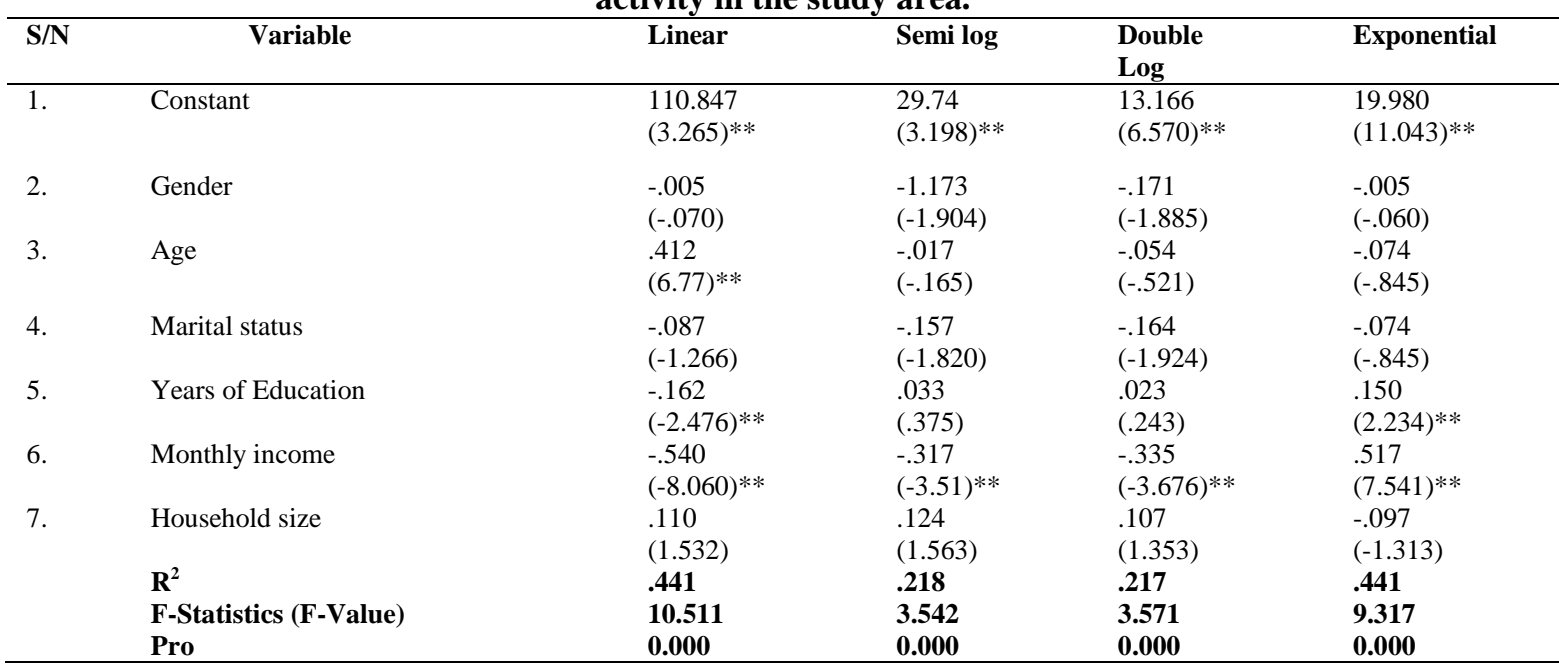

Figures in the first row are regression Coefficients, t-ratios are in parentheses

$*$ t-ratios significant at 0.05 probability level, $* *$ t-ratios significant at 0.01 probability level

Source: computed from survey data, 2012

\section{Conclusion and recommendation}

This study confirms that farming is the sustainable livelihood of the rural dwellers in southeast Nigeria. The major socio-economic factors that affect livelihood choice of rural dwellers in the place are age, number of years in school and monthly income. Based on the result of the study it was recommended that government should invest more fund in agriculture in order to develop the sector and make it attractive to graduates of agriculture.

\section{References}

[1]. Adesope, O.M, Ifeanyi-obi, C.C and Aboh, C.L. Socio-economic factors affecting rural household expenditure on mobile phone services. Journal of nature science and Sustainable technology. Vol. 5(3). 2011. USA.

[2]. Adi, B. (2007) Determinants of agricultural and non-agricultural livelihood strategies in Rural communities; Evidence from Eastern Nigeria. The Journal of developing areas, volume 40, number 2, spring spring 2007.Pp 93-94

[3]. Akpabio (2005). Rural and Agricultural Soicology. In: Ike Nwachukwu (ed) (2005). Agricultural Extension and Rural sociology. Snaap Press Ltd, Enugu.

[4]. Bryceson, D. F.: 2002, 'The Scramble in Africa: Reorienting Rural Livelihoods'. World Development, $725-739$.

[5]. Carney, D. (1998). Sustainable rural livelihoods: what contribution can we make? Conference proceedings of the International Development's National Resources advisers' conference, July 1998pp428

[6]. Chukwuezi, B.: 2001, 'Through Thick and Thin: Igbo Rural-Urban Circularity, Identity and Investment'. Journal of Contemporary African Studies (1).

[7]. Ekong E.Ekong (2010). Rural sociology. Dove Educational Publishers. Uyo, Nigeria.

[8]. Ifeanyi-obi, C.C., Asiabaka, C.C., Adesope, O.M., Issa, F.O. Inhabitants perception of climate change,effects and adaptation strategies in Etche local government area of Rivers state, Nigeria. Research India publications, Global journal of applied Agricultural research, Vol. 1 (1), 2011. India.

[9]. Igben, M. S (1988). Farmer's capability profile: M. S Igben (ed). The Nigerian farmer and Agricultural Institution. An assessment of NISER Ibadan, Nigeria. Pp $657-92$.

[10]. Maegher, K.: 2001, 'The Invasion of the Opportunity Snatchers: The Rural-Urban Interface in Northern Nigeria'. Journal of Contemporary African Studies (1).

[11]. Mgbada, J. U. (2010): Agricultural Extension: The Human Development Perspective. Computer Edge Publishers Enugu.

[12]. Nzeh E.C and Eboh O.R. (2010). Technological Challenges of Climate Change Adaptation in Nigeria: Insights from Enugu State. African Technology Policy Studies Network working paper. Series No 52. 